\title{
DIRECT SALE AS ONE OF THE ORGANIZATIONAL FORMS OF LOCAL FOOD SYSTEMS. THE SPATIAL CONCENTRATION OF DIRECT SALE ENTITIES IN POLAND
}

\author{
SPRZEDAŻ BEZPOŚREDNIA JAKO JEDNA Z FORM ORGANIZACYJNYCH \\ LOKALNYCH SYSTEMÓW ŻYWNOŚCIOWYCH. KONCENTRACJA PRZESTRZENNA \\ PODMIOTÓW SPRZEDAŻY BEZPOŚREDNIEJ W POLSCE
}

https://doi.org/10.34739/zn.2021.56.05

\author{
Ola Bareja-Wawryszuk ${ }^{1}$, Tomasz Pajewski ${ }^{2}$ \\ ${ }^{1}$ Poland, Siedlce University of Natural Sciences and Humanities, Faculty of Social Sciences \\ ola.bareja-wawryszuk@uph.edu.pl; ORCID: 0000-0002-3791-5736 \\ 2 Poland, Helena Chodkowska University of Technology and Economics, \\ Faculty of Management and Logistics \\ tomasz.pajewski@uth.edu.pl, ORCID: 0000-0001-7058-6375
}

JEL Classification Codes: C31, 013, Q01, Q12

\begin{abstract}
Direct selling is one of the most common local activities in the agri-food sector. Contemporary trends in the production and consumption of food indicate a duality of food systems in which the concept of the industrialization of the agri-food sector is simultaneously developing together with a concept of local food systems. In this article, it is shown that the direct selling of agri-food products is in line with the contemporary trends in the agri-food sector, and that it is important to analyze its spatial patterns. Taking into account the spatial concentration of direct selling entities, it has been proved that their distribution is random and does not show clustering patterns.
\end{abstract}

Key words: direct sale, local food systems, spatial concentration, autocorrelation

Streszczenie: Sprzedaż bezpośrednia jest jedną z najbardziej powszechnych form prowadzenia działalności lokalnej w sektorze rolno-spożywczym. Współczesne tendencje w produkcji i konsumpcji żywności wskazują na dualizm systemów żywnościowych, w którym równocześnie następuje rozwój koncepcji industrializacji sektora rolno-spożywczego oraz rozwój lokalnych systemów żywnościowych. W artykule scharakteryzowano sprzedaż bezpośrednią w Polsce, a także dostrzeżono, iż sprzedaż bezpośrednia wpisuje się we współczesne tendencje sektora rolno-spożywczego. Głównym celem artykułu była identyfikacja zależności przestrzennych pomiędzy podmiotami sprzedaży bezpośredniej. Konstruując miary autokorelacji przestrzennej dowiedziono, że rozmieszczenie podmiotów sprzedaży bezpośredniej ma charakter losowy i nie wykazuje tendencji do klasteryzacji. Słowa kluczowe: sprzedaż bezpośrednia, lokalne systemy żywnościowe, koncentracja przestrzenna, autokorelacja

\section{Introduction and theoretical background}

Observing contemporary trends in the production and consumption of food, many definitions of direct links between food producers and end consumers operating in a limited geographical area can be distinguished (Balazs et al., 2013). Phenomena such as: direct sales, the shortening of supply chains, extensive agriculture, processing with traditional methods or local consumption appear in the literature under numerous names (Fegan,
2007). Trends in the agribusiness sector that indicate the reorganization of conventional supply chains, a return to direct producer-consumer relationships and the regionalization of food production are called local food systems. In the literature, various definitions of local food systems can be find. According to Blouin et al. (2009), local food systems are identified as an effective way to achieve food sovereignty, defined as the society's right to access local, healthy and ecological food, produced with respect for each partner in the 
Bareja-Wawryszuk O., Pajewski T., DIRECT SELLING AS ONE OF THE ORGANIZATIONAL FORMS OF LOCAL FOOD SYSTEMS. THE SPATIAL CONCENTRATION OF DIRECT SALE ENTITIES IN POLAND, Zeszyty Naukowe Uniwersytetu Przyrodniczo-Humanistycznego w Siedlcach Nr 129, Seria: Administracja i Zarządzanie (56) 2021

supply chain, and providing it with appropriate conditions, work and adequate remuneration. Also, three criteria are commonly used to characterize local food systems. The first criterion, the geographical criterion, assumes a certain distance between the consumer and the producer. Some sources say that the distance ranges from $20 \mathrm{~km}$ to $100 \mathrm{~km}$ (Balazs et al., 2013) or even from $80 \mathrm{~km}$ to over $100 \mathrm{~km}$ (Brown, Miller, 2008). In Poland, the spatial dimension of local food systems is often reduced to the administrative area, i.e. one voivodeship. The ambiguity of this criterion justifies the use of subsequent ones. The term "local food system" is used when the number of entities in the supply chain is minimal (llbery and Maye, 2006). This is important not only as a determinant of quality, authenticity and freshness, but also as a way for the producer to achieve tangible economic benefits. The last criterion for defining local food systems concerns direct relations between system participants. It supports the creation of social ties, influencing the improvement of the functioning of the local community, and also create a sense of belonging to the region (Devon County Council, 2011). Another approach to local food systems can be the definition proposed by Working Group on Local (2003), where local food systems are "produced, processed and sold in a specific geographical area, economically effective for producers, processors and sellers, healthy, traded fairly, workers' rights are not abused, production techniques are environmentally friendly, respecting the food culture".

As of January 1, 2018, there are 12765 entities in Poland involved in the production, processing and sale of local animal products. The most numerous group are entities operating under direct sales. Direct sales involve making the unprocessed products of animal origin available to the final recipient, bypassing intermediaries. The possibility of direct sales applies only to products manufactured from own raw materials and made available in the area of the voivodeship where the production takes place or in the area of the neighbouring voivodeships. In special cases, e.g. during exhibitions, fairs organized to promote local products, it is allowed to sell in other provinces (Regulation of the Minister of Agriculture and Rural Development of 30 September 2015, 2015). The volume of production and sale of the above mentioned products is strictly defined and should not exceed the limits imposed by the act. Direct sales product distribution channels include:

- places where the production of products for direct sale takes place, including the spheres of farms, apiaries or fishing farms;
- markets;

- mobile objects or devices, or temporary means of transport located within the production area, inside or outside of marketplaces:

- establishments engaged in retail trade for the final consumer.

In the case of milk, it is allowed to sell from distribution equipment intended for the sale of food. Direct sales to the final consumer may also take place by way of electronic means, by mail order and in the system of direct deliveries to the consumer, as part of the so-called cooperative. Manufacturing sites for products intended for direct sale should be in buildings or adapted rooms separate from living quarters. All facilities and equipment used in production under direct sales must meet sanitary requirements and ensure the safety of the production process. The most restrictive veterinary requirements apply to places where carcasses, offal of poultry, lagomorphs or game animals are sold, as well as fishery products subjected to bleeding, head removal, removal of fins or evisceration. A convenience for direct sales entities is the lack of the need to fully implement the HACCP system and less frequent control by the Chief Veterinary Inspectorate (Rozporządzenie..., 2015). Entities conducting direct sales are required to keep documentation confirming the number of products sold, including the results of water control and confirmation by a doctor of the ability to perform work related to food production. All products sold by direct sale should be properly labelled, thus allowing the traceability of the food. The authority registering and supervising direct sales is the Chief Veterinary Inspectorate. Detailed guidelines specifying the conditions for conducting direct sales are included in the Regulation of the Minister of Agriculture and Rural Development of 30 September 2015 on veterinary requirements for the production of animal products intended for direct sale.

Local direct selling entities constitute the most numerous group among the various organizational forms of local food systems. In January 2018, 9,340 entities were registered in Poland. The number of registered entities shows a constant upward trend (Chief Veterinary Inspectorate, 2018). Direct sale covers 8 product categories, i.e. poultry, lagomorphs, game animals, fishery products, live snails, milk and cream, eggs, unprocessed bee products. The most numerous group are entities selling unprocessed bee products, i.e. $73 \%$ of all direct sales entities, entities selling eggs (12.9\%) and entities offering fishery products $(9.5 \%) \quad$ (Chief Veterinary Inspectorate, 2018). 
The largest number of entities selling directly in absolute terms operates in the following voivodeships: wielkopolskie (kalisz and gniezno poviats), dolnośląskie (kłodzko and Jelenia Góra poviats) and Śląskie (bielski and pszczyna poviats). $42.3 \%$ of all direct sale entities are concentrated in these three voivodeships. On the other hand, the voivodeships with the lowest number of direct sales entities are the following voivodeships: (Brzeski poviats, Namysłowski poviats, city of Opole), Podlaskie (city of Białystok, Bielski poviats), Świętokrzyskie (Sandomierski poviats, city of Starachowice).

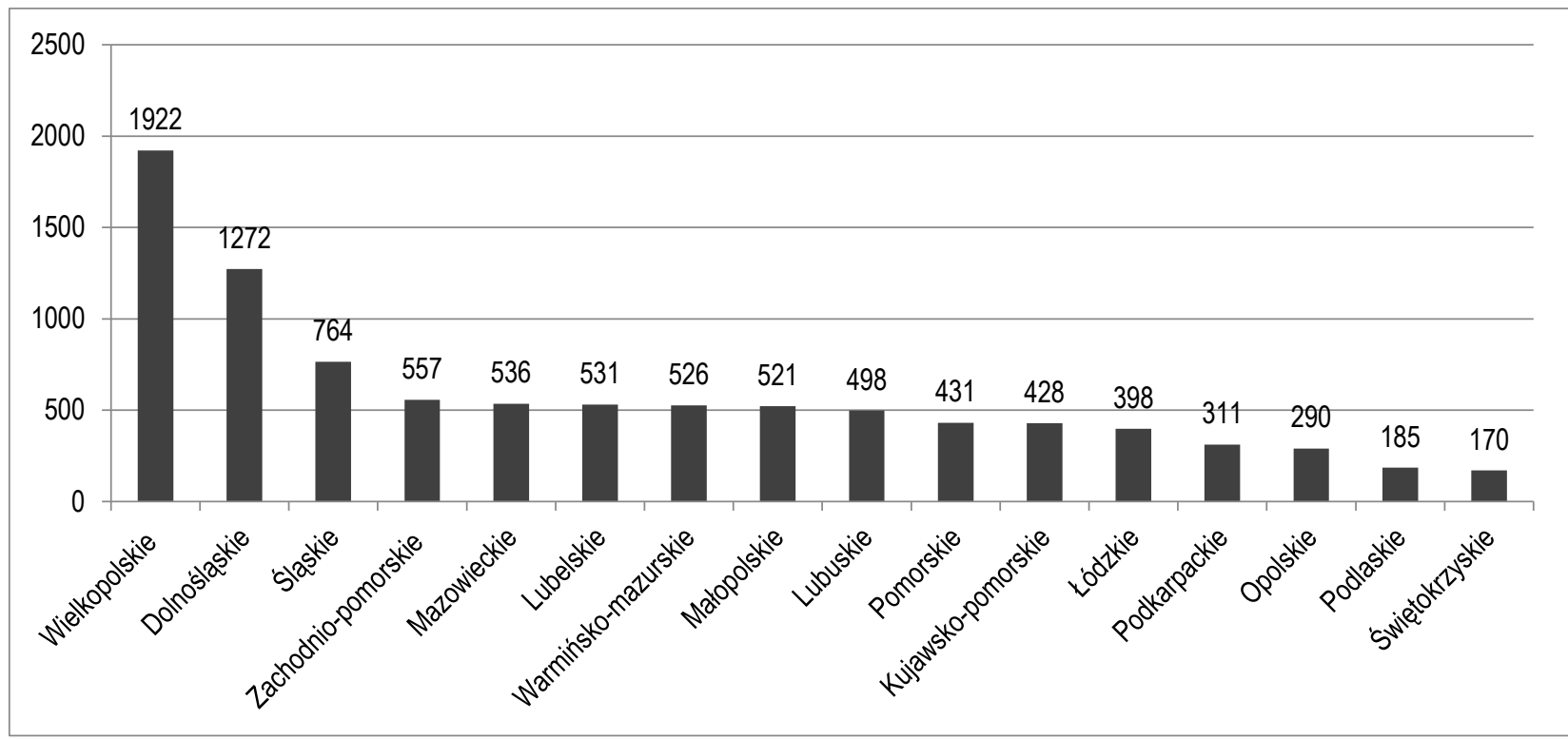

Figure 1. Direct sales entities by voivodships in 2018

Source: own study based on CVI, 2018.

The concentration processes of economic entities observed in geographic space provide valuable information on the functioning of regional economies and the directions of their development. Thus, it is justified to undertake research that enables the improvement of the concept of business development within local food systems in spatial systems. The concept of spatial concentration of economic activity has many definitions. It is common to meet the definition of spatial concentration as a process of domination, focusing activities in the system of sectoral structure (Kopczewska et al., 2016). However, the literature distinguishes between explaining spatial concentration in terms of geography and economy. The geographical definition explains the concentration of economic activity as: "its share in relation to the structure of the economy occurring in the adopted reference system of spatial aggregates corresponding to territorial division units" (Kopczewska et al., 2016). In economic terms the spatial concentration of economic entities means their share in the general structure of the economy of a given area. Concentration in the above sense is also called production concentration (Zheng, Kuroda, 2013) or absolute concentration (Haaland et al., 1999). It is noted in the literature that spatial concentration always has both economic and geographical dimensions, and the tools used to identify concentration are methods based on the theory of clustering (Kopczewska et al., 2016). An important element of the analysis of spatial concentration are spatial autocorrelation measures.

Spatial autocorrelation is used to evaluate the relationship between variables with respect to spatial location, wherein close observations are more similar to observations that are distant from each other (Kopczewska, 2010). Correlation relationships can take two variants, i.e. positive and negative. Positive spatial autocorrelation means grouping the observed phenomena into clusters, while negative - means their dispersion (Suchecki, 2010). The analysis of the spatial effects of local food systems may affect the understanding of the mechanisms of strengthening or weakening the functioning of the studied entities through proximity to other territorial units.

\section{Sources and methodology of research}

The main purpose of this article was to identify and evaluate the spatial concentration of entities involved in the production, sale and processing of 
animal products that make up local food systems, i.e. direct sales entities. Hypothesis needed to be proved was that direct sale entities has a tendency for clustering. In order to identify the spatial relationships of direct sales entities, global and local statistics of the Moran / spatial autocorrelation and the Getisa-Orda $G$ index were calculated. Information was obtained whether the examined objects are distributed in space in a random or clustered manner. Local statistics were constructed for individual regions to indicate whether a given region is similar in terms of the studied variable or is different from its neighbouring regions. The visualization of the obtained results is presented on the scatter plot. The calculations were made in the R CRAN program. Formula 1 was used to construct the global Moran / statistic:

$$
I=\frac{N}{\sum_{i} \sum_{j} w_{i j}} \frac{\sum_{i} \sum_{j} w_{i j}\left(X_{i}-\bar{X}\right)\left(X_{j}-\bar{X}\right)}{\sum_{i}\left(X_{i}-\bar{X}\right)^{2}}
$$

where:

$X_{i}-$ value of the attribute of the object $i$,

$X_{j}-$ value of the object attribute $j$,

$N$ - number of objects,

$w_{i j}$ - weight of object connections $i$ and $j$,

$\bar{X}-$ average value of the variable for all objects.

The calculations were made at the level of 16 voivodeships. The randomization method was used in the calculations, and the alpha value was set at 0,05. Moreover, the global Moran I statistic was calculated on the basis of four different weight matrices, i.e.: binary first-order neighbourhood matrix, matrix of 5 nearest neighbours, matrix of neighbours within a radius of $200 \mathrm{~km}$ and weight matrix according to the reciprocal distance criterion. The appropriate selection of the type of weight matrix is a key element of the spatial autocorrelation calculation process and may have a significant impact on the result of the analysis (Głowicka-Wołoszyn et al., 2017). Therefore, as Getis and Aldstadt (2010) point out, when calculating the spatial autocorrelation measures, both weight matrices taking into account the distances between objects as well as the direct neighbourhood should be taken into account. This approach makes it possible to compare the obtained results.

To calculate the local Moran / statistics, a firstorder row-standardized neighbourhood matrix was used. Formula 2 was used in the calculations:

$$
I_{i}=\frac{\left(X_{i}-\bar{X}\right) \sum_{i=1}^{n} w_{i j}\left(X_{j}-\bar{X}\right)}{\sum_{i=1}^{n}\left(X_{i}-\bar{X}\right)^{\wedge} 2 / N}
$$

where:

$N$ - number of spatial objects,

$X_{i}, X_{j}$ - value of variables in the spatial unit $i$ and $j$,

$X-$ average value of the variable for all objects,

$w_{i j}$ - elements of a spatial weight matrix,

$\sum_{i=1}^{N}\left(X_{i}-\bar{X}\right)^{\wedge} 2 / N$ - variance.

The second global measure of autocorrelation used in the study was the GetisOrda $G$ index. This statistic allows for the identification of the so-called hot spot, i.e. clusters with high levels of facility value, and cold spotclusters with low levels of facility value. The assumption of the Getis-Orda $G$ index is to compare, at a certain distance, the sum of the variable values in the neighbouring areas with the sum of the variable values in all areas. In this article, the calculations were made on the basis of a binary neighbourhood matrix not standardized with lines according to the formula 3 :

$$
G(d)=\frac{\sum_{i=1}^{N} \sum_{j=1}^{N} w_{i j}(d) X_{i} X_{j}}{\sum_{i=1}^{N} \sum_{j=1}^{N} X_{i} X_{j}}
$$

where:

$w_{i j}$ - elements of a spatial weight matrix,

$X_{i}, X_{j}$ - value of variables in the spatial unit $i$ and $j$,

$d$ - the maximum distance within which the appearance of clusters is expected.

In order to precisely analyze the spatial relations, local Getis-Orda $G$ statistics were calculated. Formula 4 was used in the calculations:

$$
G_{i}(d)=\left(\sum_{j, j \neq i}^{N} w_{i j} X_{j}\right) /\left(\sum_{j, j \neq i}^{N} X_{j}\right)
$$

where:

$N$ - number of spatial objects,

$X_{i}, X_{j}$ - value of variables in the spatial unit $i$ and $j$,

$w_{i j}$ - elements of the spatial weight matrix.

\section{Results and Discussion}

Table 1 shows the results of the global Moran / statistics for direct sales entities at the voivodeship level. Moran I statistics calculations are made on the basis of several types of matrix weights in order to compare the results and choose the most statistically significant. In the binary matrix of weights according to the common border criterion, the average number of neighbours was 4.25. However, in the matrix of 5 closest neighbours, the average number of connections was 6.125 . In the case of a weight matrix with 5 nearest neighbours, each region was connected to the 5 closest neighbours, but when 
the neighbour regions are at the same distance, the region is connected to more than one region. However, based on the coordinates of the area centres, a matrix was created according to the criterion of neighbourhood within a radius of 200 $\mathrm{km}$. In this case, the neighbour was the object the centre of which is not more than $200 \mathrm{~km}$ in a straight line. The average number of links in this type of matrix was 3.5. The last matrix of weights was created using the reciprocal distance criterion. In this case, the average number of connections was 4.25. However, all the obtained results of the Moran / global statistics are statistically insignificant, because the $p$ value is high and exceeds the assumed level of alpha $=0.05$.

Table 1. Values of Moran I global statistics for direct sales

\begin{tabular}{|c|c|c|}
\hline Type of weight matrix & $\begin{array}{l}\text { Global } \\
\text { Value of } \\
\text { Moran } I .\end{array}$ & $P$ value \\
\hline $\begin{array}{l}\text { First order binary } \\
\text { neighborhood matrix }\end{array}$ & -0.12 & 0.68 \\
\hline $\begin{array}{l}\text { Matrix of the } 5 \text { closest } \\
\text { neighbors }\end{array}$ & -0.05 & 0.44 \\
\hline $\begin{array}{l}\text { Matrix of neighbors } \\
\text { within a radius of } 200 \\
\mathrm{~km}\end{array}$ & -0.06 & 0.50 \\
\hline $\begin{array}{l}\text { Matrix of weights } \\
\text { according to the } \\
\text { reciprocal distance } \\
\text { criterion }\end{array}$ & -0.12 & 0.66 \\
\hline
\end{tabular}

Source: own calculations in R CRAN.
Thus, from a global perspective, there is no spatial autocorrelation between direct sale entities. It can be assumed that direct sale entities are randomly located in Poland. The lowest value of $p$ is derived from the matrix 5 nearest neighbours, thus it was used to construct a graph statistics Moran I. A graphical presentation of global statistics Moran $I$ is a scatter plot shown in Figure 1. The graph on the x-axis, described as a "SB.std" hook has a variable, i.e. the number of direct sales entities in each voivodeship in Poland, subjected to standardization, i.e. expressed as the number of deviations from the sample mean and divided by the standard deviation. The tested standardized and spatially delayed variable is placed on the $\mathrm{Y}$ axis. The Moran / statistic is a slope in the regression line with a negative slope.

The distribution of points in relation to the four quarters of the graph indicates the type of spatial autocorrelation taking place. Based on the Figure 2 , the points mainly belong to the second and third quadrants of the graph. Objects located in the second and fourth quadrants of the graph (upper left and lower right part of the graph) are characterized by a negative spatial autocorrelation, i.e. voivodeships with a small number of direct sales entities are surrounded by voivodeships with a high value of the observed variable.

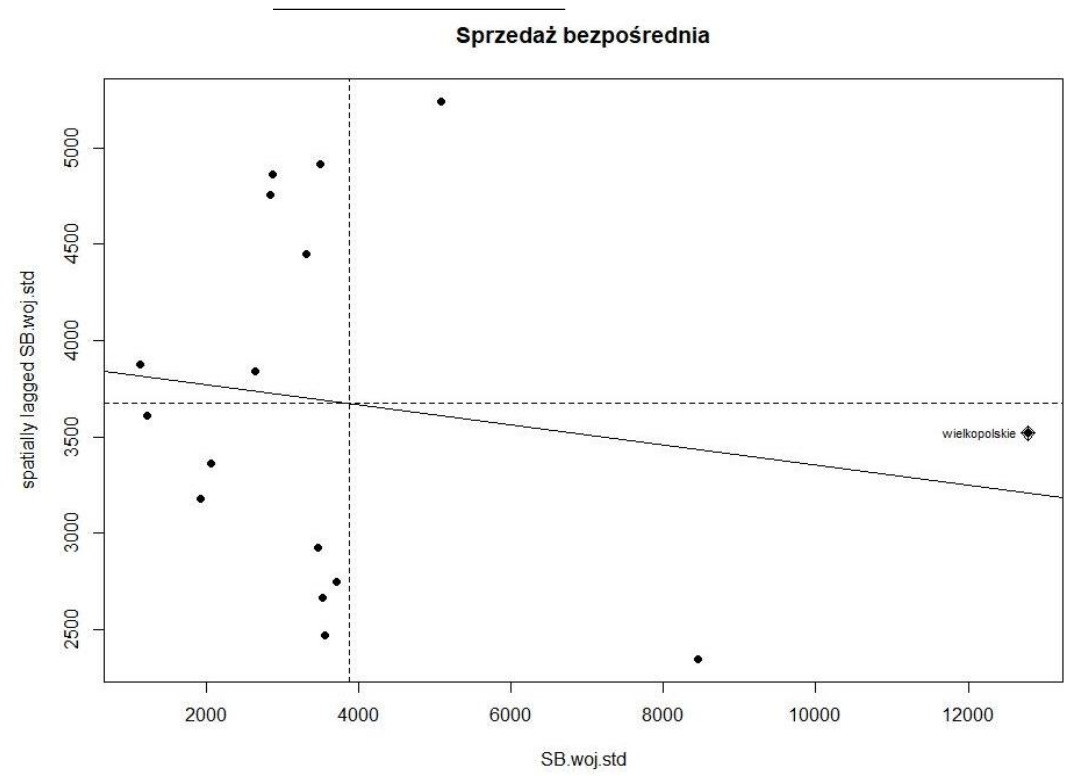

Figure 2. Graphical interpretation of the global Moran / statistics for direct sales at the voivodeship level Source: own study in R CRAN. 
On the other hand, the entities in the third quadrant (lower left part of the graph) show a positive spatial autocorrelation, i.e. individual regions with high values of the variable are surrounded by regions also with high values of the variable. Below the regression line there are 8 observations, which means that in these regions the values of the variable, i.e. direct sales, exceed the values in the neighbouring regions much more than it would appear from the general spatial pattern. Figure 1 also shows the outlier, i.e. the Wielkopolskie voivodeship. Then, the level of spatial autocorrelation between individual regions was checked. For this purpose, local Moran / statistics were calculated. Moran / statistics make it possible to find spatial autocorrelation for each analyzed location in which local food systems function. These measures allowed at a later stage of the work to precisely identify clusters of large or small values of the variable and to indicate atypical observations between individual voivodeships. The matrix of 5 nearest neighbours as well as the matrix of weights was used. Table 2 shows the results obtained.

Table 2. Values of local Moran / statistics for direct sales

\begin{tabular}{ccc}
\hline Voivodeship & $\begin{array}{c}\text { Local value } \\
\text { of Moran } \boldsymbol{l} .\end{array}$ & $\boldsymbol{P}$ value \\
\hline 1 & -0.88 & 1.00 \\
2 & -0.11 & 0.56 \\
3 & 0.05 & 0.32 \\
4 & -0.04 & 0.47 \\
5 & 0.01 & 0.40 \\
6 & 0.05 & 0.36 \\
7 & 0.06 & 0.36 \\
8 & 0.17 & 0.21 \\
9 & 0.12 & 0.25 \\
10 & 0.09 & 0.22 \\
11 & -0.12 & 0.57 \\
12 & 0.20 & 0.18 \\
13 & 0.00 & 0.41 \\
14 & -0.05 & 0.48 \\
15 & -0.40 & 0.84 \\
16 & 0.03 & 0.39 \\
\hline
\end{tabular}

Source: own calculations.

The obtained results did not show spatial relationships and are not statistically significant. Increasing the alpha level to 0.10 also did not obtain statistically significant results. It can be assumed that the direct sales entities are distributed randomly.

Another global measure of spatial autocorrelation used in the study is the Getis-Orda index. The results of the Getis-Orda $G$ statistics are presented in Table 3.

Table 3. Global Getis-Orda G statistics for direct sales

\begin{tabular}{lc}
\hline Index & Value \\
\hline$P$ value & 0.73 \\
Global statistics of Getis- & $\mathbf{0 . 2 4}$ \\
Orda G & \\
\hline
\end{tabular}

Source: own calculations.

The obtained results at the voivodeship level do not provide reasons for identifying the spatial autocorrelation and the type of clusters, because obtained $p$ value is very high and exceeds the assumed significance level of alpha $=0.05$.

Following this, in order to precisely analyze the spatial relationships, local Getis-Orda $G$ statistics were calculated. Assuming the alpha level $=0,05$, statistically significant results were obtained for the Podlaskie and Podkarpackie voivodeships. This means that in these voivodeships it is probable that entities with high values of the examined variable are adjacent to similar entities, also with high values of the variable (Fig. 3).

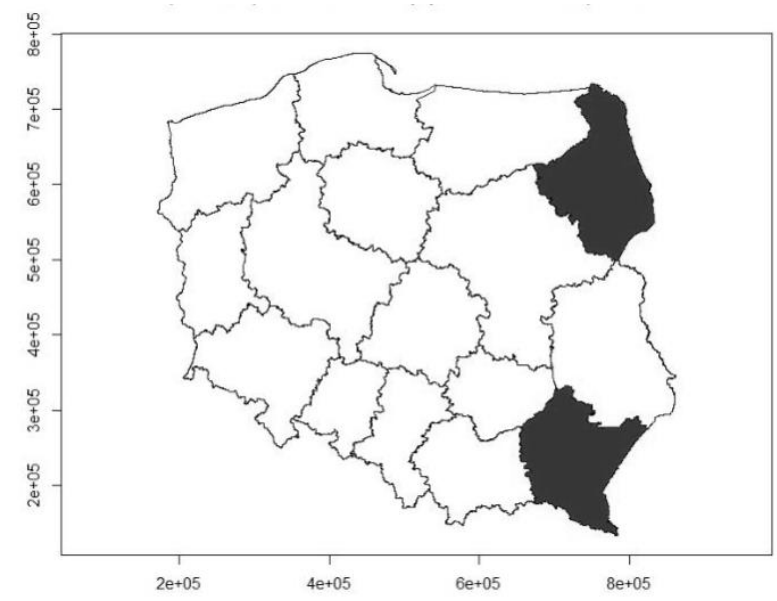

Figure 3. Graphical presentation of local Getis-Orda G statistics for direct sales at the voivodeship level Source: Own study in R CRAN.

\section{Conclusions}

This article analyzes direct sales entities. These entities are part of local food systems involved in the production, processing and sale of animal products. Local food systems create an alternative approach to the production, distribution and consumption of agri-food products, gaining in popularity nowadays. Based on the literature study and observations of local entities, it can be concluded that local food systems are systems that fit into the philosophy of sustainable 
development of the region. The research process was carried out to systematize the theory of direct sales and local food systems and to evaluate their spatial relationships. The following tools were used to achieve the above goals: literature study, graphical presentations of the spatial structure, global and local statistics of the spatial autocorrelation Moran / and the Getisa-Orda index by $G$.

The obtained results of the spatial concentration indicate the lack of spatial relations between the entities, which allows to assume that the spatial distribution of variables is random. Thus, tested hypothesis has been rejected. At the voivodeship level, the number of statistically significant results was low. Statistically significant values were obtained only at the level of local measures. Thus, the spatial structure of the analyzed entities is random, and the formation of cluster structures is observed only in a small number of locations.

\section{References}

Balázs, B., Blackett, M., Bos, E., Eyden-Wood, T., Gomez, Y., Paloma, S., Kneafsey, M., Trenchard, L. (2013). Short food supply chains and local food systems in the EU. A state of play of their socio-economic characteristics. European Union: Publications Office of the European Union.

Blouin, C., Lemay, J.-F., Ashraf, K., Imai, J., Konforti, J. (2009). Local food systems and public policy: a review of the literature. Equiterre \& The Centre for Trade Policy and Law, Carleton University.

Brown, C., Miller, S. (2008). The impacts of local markets: A review of research on farmers markets and community supported agriculture (CSA). American Journal of Agriculture Economics, 90, 1296-1302.

Department for Environment, Food and Rural Affairs UK. Working Group on Local, (2003). Local food - a snapshot of the sector. Retrieved from: http://www.tourisminsights.info/ONLINE PUB/FARMING\%20AND\%20FOOD/FOOD\%2 OPDFS/LOCAL\%20FOOD.pdf

Devon County Council. (2011). A Local Authority Survey: Buying food with geographical descriptions, How "local" is "local"? United Kingdom.

Fegan, R. (2007). The place of food: mapping out the 'local' in local food systems. Progress in Human Geography, 31, 1, 23-42.

Getis A., Aldstadt J. (2010). Constructing the spatial weights matrix using a local statistic, [in:] Anselin L., Rey S.J. (ed.), Perspectives on Spatial Data Analysis, Springer, Berlin.
Głowicka-Wołoszyn, R., Kozera, A., Wysocki, F. (2017). Problem doboru macierzy wag przestrzennych w identyfikacji efektów przestrzennych samodzielności finansowej gmin [Selecting the matrix of spatial weights in the identification of the spatial effects of the financial independence of communes]. Prace Naukowe Uniwersytetu Ekonomicznego we Wrocławiu, 468, 89-98.

Chief Veterinary Inspectorate, (2018). Lista podmiotów zakwalifikowanych do sprzedaży bezpośredniej [The list of entities qualified to engage in direct selling].

https://pasze.wetgiw.gov.pl/spi/ demosb/index.php.

Haaland, J.I., Kind, H.J., Midelfart-Knarvik, K.H., Torstensson, J. (1999). What determines the economic geography of Europe. CEPR Discussion Paper, 2072.

Ilbery, B., Maye, D. (2006). Retailing local food in the Scottish-English borders: A supply chain perspective. Geoforum, 37, 3, 352-367.

Kopczewska, K., Churski, P., Ochojski, A., Polko, A. (2016). Specjalizacja regionalna - systematyzacja pojęć i metod pomiaru [Regional specialization - the systematization of concepts and methods of measurement]. Studia Regio-nalia, 170, 8-25.

Rozporządzenie Ministra Rolnictwa i Rozwoju Wsi z dnia 30 września 2015 r. w sprawie wymagań weterynaryjnych przy produkcji produktów pochodzenia zwierzęcego przeznaczonych do sprzedaży bezpośredniej [Regulation of the Minister of Agriculture and Rural Development of 30 September 2015 on veterinary requirements for the production of animal products intended for direct sale], Dz.U. poz. 1703.

Suchecki, B. (2010). Ekonometria przestrzenna, Metody i modele analizy danych przestrzennych [Spatial Econometrics, Methods and Models for Spatial Data Analysis]. Warszawa: Wyd. C.H. Beck.

Zheng, D., Kuroda, T. (2013). The impact of economic policy on industrial specialization and regional concentration of China's high-tech industries. The Annals of Regional Science, Springer, 50, 3, 771-790. 